\title{
An uncommon cause of warm foot
}

\author{
Kanhaiya Agrawal, ${ }^{1}$ Kripa Elizabeth Cherian, ${ }^{1}$ Julie Hephzibah, ${ }^{2}$ Nihal Thomas ${ }^{3}$
}

'Department of Endocrinology, Christian Medical College, Vellore, India

${ }^{2}$ Department of Nuclear Medicine, Christian Medical College, Vellore, India ${ }^{3}$ Department of Endocrinology, Diabetes and Metabolism, Christian Medical College, Vellore, India

Correspondence to Dr Nihal Thomas, nihal_ thomas@yahoo.com

Accepted 21 June 2017 CrossMark

\section{To cite: Agrawal K,} Cherian KE, Hephzibah J, et al. BMJ Case Rep Published Online First: [please include Day Month Year]. doi:10.1136/bcr-2017219465

\section{DESCRIPTION}

A 66-year-old man presented with swelling and redness of right foot of 1 month duration. He was a known diabetic for 20 years; glycaemic control was suboptimal. There was no history of trauma, fever, ulcer or deformity. He had numbness of both feet and was earlier documented to have mild non-proliferative diabetic retinopathy. On examination, he was not feverish with erythema, swelling (figure 1), local rise of temperature of the right foot and a difference of $2{ }^{\circ} \mathrm{C}$ between both feet and no tenderness on palpation. There was loss of protective sensations with absent ankle jerks with bounding pulses in both feet. Systemic examination was unremarkable. His blood investigations revealed haemoglobin of $12 \mathrm{~g} / \mathrm{dL}(\mathrm{N}$ 12-15), total white cell count of $9.8 \times 10^{9} / \mathrm{L} /$ cmm (N 4000-11000), erythrocyte sedimentation rate of $48 \mathrm{~mm} /$ hour and haemoglobin A1c of $8.1 \%(\mathrm{n}<5.7)$. Based on history and clinical findings and absent elevation of acute inflammatory markers, a diagnosis of acute Charcot foot was considered. An X-ray of the right foot (figure 2A) displayed areas of sclerosis and lysis of the medial cuneiform, and technetium 99m-methylene diphosphonate scan (figure 2B) demonstrated an intense uptake in the joints of the right midfoot, suggestive of acute Charcot foot. $\mathrm{He}$ was off-loaded with total contact cast and started on alendronate. Patient was reviewed after 1 month and there were no symptoms like fever or pain. However, this time, his X-ray of the foot showed worsening in the form of further sclerosis and osteolysis of the tarsal bones (figure 2C). He was continued on off-loading with total contact cast.

Charcot foot, otherwise known as neuroarthropathic foot, is a condition affecting bones, joints and soft tissues of the foot and ankle. It was initially described in conditions like Hansen's disease and

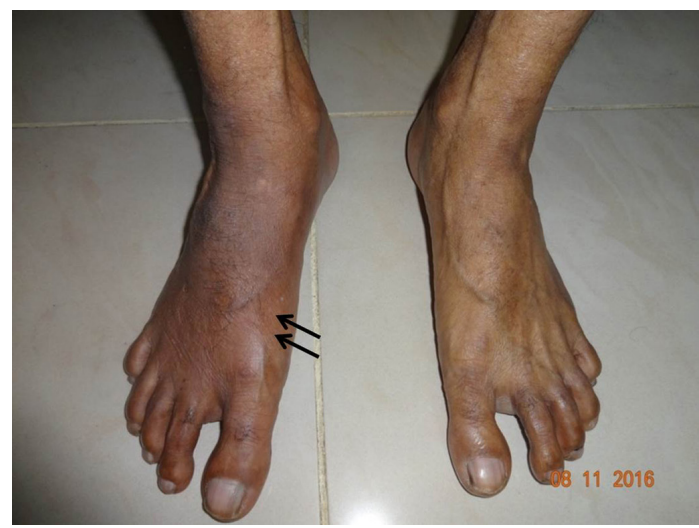

Figure 1 Picture showing right foot of the patient with erythema and swelling.

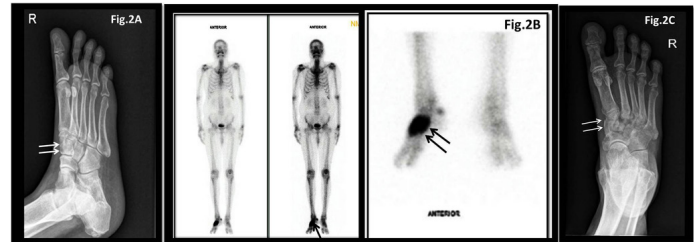

Figure 2 (A) X-ray of the right foot (antero oblique view) displaying sclerosis and lysis of the tarsal bones. (B) Bone scan showing increased tracer uptake in the joints of the right mid-foot. (C) - X-ray of right foot showing worsening of sclerosis and osteolysis of tarsal bones.

Learning points

Acute Charcot foot is commonly seen in subjects with diabetes mellitus who have peripheral neuropathy and autonomic neuropathy.

- A high index of suspicion is needed to diagnose this condition at an early stage as off-loading will help in halting the progression and preventing permanent deformity.

- Differential diagnoses for this condition include infective conditions like cellulites, osteomyelitis and arthritis and non-infective conditions such as gout and deep vein thrombosis.

syphilis, now in subjects with poorly controlled diabetes who have both peripheral neuropathy and autonomic neuropathy in the absence of peripheral vascular disease. Diagnosis needs high index of suspicion and it has to be differentiated from conditions like cellulites, osteomyelitis and septic arthritis. X-rays of the foot may not show significant changes in the early stages. ${ }^{1}$ The MRI criteria for Charcot neuroarthropathy are periarticular focal bone marrow oedema, absent sinus tracts, soft-tissue fluid accumulation and relative preservation of periarticular subcutaneous fat. Bone scintigraphy has a sensitivity of $80 \%-100 \%$, although it is not very specific $(25 \%-60 \%)$. It can be used in those with metallic implants. A negative test excludes an infective aetiology. ${ }^{2}$ The mainstay of management is 'off-loading' the affected limb so as to ensure adequate immobilisation and to avoid the weight bearing stress. Application of total contact cast is regarded as the 'gold standard technique' in off-loading. It helps in immobilisation, even distribution of plantar pressures, thereby reducing inflammation and helping in resolution of further bone destruction. ${ }^{1}$ There is very limited 
Images in...

evidence available for use of bisphosphonates in acute Charcot foot and prospective studies are needed in this regard.

Contributors KA and KEC wrote the manuscript. JH and NT reviewed the manuscript. KA, KEC, JH and NT approved the manuscript.

Competing interests None declared.

Patient consent Obtained.

Provenance and peer review Not commissioned; externally peer reviewed. (c) BMJ Publishing Group Ltd (unless otherwise stated in the text of the article) 2017. All rights reserved. No commercial use is permitted unless otherwise expressly granted.

\section{REFERENCES}

1 Mascarenhas JV, Jude EB. Pathogenesis and medical management of diabetic Charcot neuroarthropathy. Med Clin North Am 2013;97:857-72.

2 Rogers LC, Frykberg RG, Armstrong DG, et al. The Charcot foot in diabetes. Diabetes Care 2011;34:2123-9.

3 Richard JL, Almasri M, Schuldiner S. Treatment of acute Charcot foot with bisphosphonates: a systematic review of the literature. Diabetologia 2012;55:1258-64.

Copyright 2017 BMJ Publishing Group. All rights reserved. For permission to reuse any of this content visit

http://group.bmj.com/group/rights-licensing/permissions.

BMJ Case Report Fellows may re-use this article for personal use and teaching without any further permission.

Become a Fellow of BMJ Case Reports today and you can:

- Submit as many cases as you like

- Enjoy fast sympathetic peer review and rapid publication of accepted articles

Access all the published articles

Re-use any of the published material for personal use and teaching without further permission

For information on Institutional Fellowships contact consortiasales@bmjgroup.com

Visit casereports.bmj.com for more articles like this and to become a Fellow 